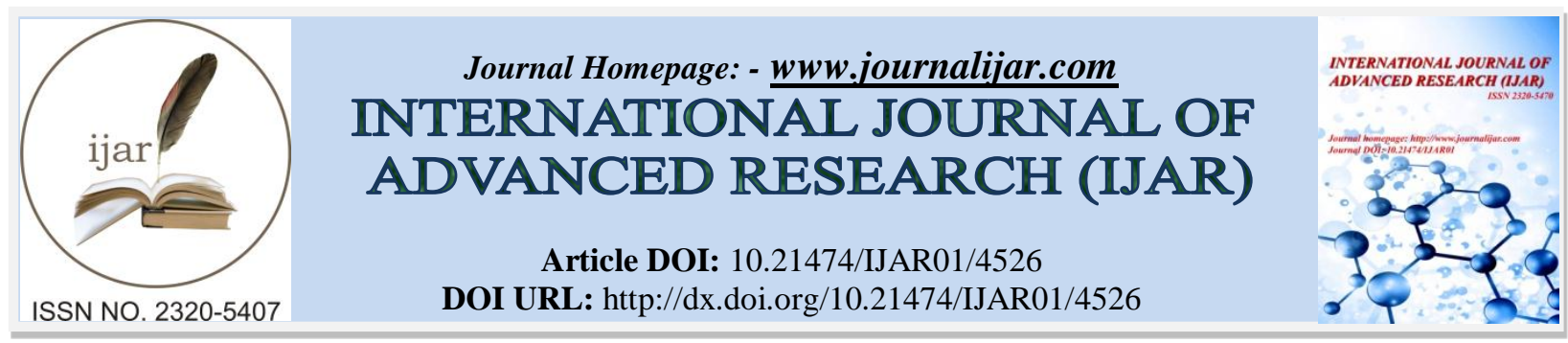

RESEARCH ARTICLE

\title{
SERVICE TENURE AND WORK LIFE BALANCE SATISFACTION-A STUDY ON SOFTWARE PROFESSIONALS IN HYDERABAD.
}

Dr. Vijaya Lakshmi Kanteti.

Director, AMS school of Informatics, OU campus, Hyderabad.

\section{Manuscript Info}

Manuscript History

Received: 19 April 2017

Final Accepted: 21 May 2017

Published: June 2017

Key words:-

Work life balance satisfaction, service tenure, software professionals.

\section{Abstract}

The purpose of the study is to investigate the relationship between the work life balance satisfaction and the Service tenure of software professionals in their work/life and its extent of impact on the WLB satisfaction. The sample consisted of 500 software professionals of three levels of designations, from Hi-tech city of Hyderabad who are both male and female. Convenience sampling technique was adopted to select the number of respondents across the three levels. Hypotheses in support of WLB satisfaction has been tested in this study. The correlation, ANOVA and regression analysis at .05 level of significance revealed positive relation between the variables under study and significant difference was found between the work life balance satisfaction level based on the service tenure and it was also found that service tenure has a positive impact on the work life balance satisfaction levels of the employees.

Copy Right, IJAR, 2017,. All rights reserved.

\section{Introduction:-}

Indian IT industry has been experiencing a tremendous growth in service sector. The Indian software sector has expanded almost twice as quickly as the world leading US software industry in recent years. The information technology (IT) sector in India holds the distinction of advancing the country into the new-age economy. Since this Industry is highly knowledge capital intensive, it requires a huge knowledge based work force, thereby leading to lots of work pressures day in and day out. It has become necessary for organizations to explore the challenges that employees face so as to build a better WLB satisfaction through innovative WLB policies. Managing the conflict between work and family responsibilities has been recognized as a critical challenge for organizations. As India continues to emerge as a global economic power, understanding the dynamics between work and personal lives is increasingly important. With work life balance becoming a cause of concern, facing the work life challenges within the sector is giving rise to problems of employee disengagement. Hence, the present study focuses on those software professionals-for whom the boundary between work and life is generally thought to be distorted and tries to find probable solutions to face the challenges faced by them regarding Work-Life Balance (WLB).

\section{Role of WLB in IT industry:-}

Work-life balance is a challenge for most of us, because work and life both come with multiple roles that we are expected to fulfil. IT sector is unique in its operational methodology while compared to manufacturing sector, where knowledge based activities are centrifugal for the business operations, the individual employees knowledge and skills are the strongest investment for the successful operations of the organisations in this sector. The employees are expected to work for long hours and flexible in their attitude towards work and work environment. It 
is being recognised as highly paying sector which attracts both fresh recruits and experienced through attractive packages and demanding profound contribution at work places. Thus, a balanced life is needed where one can spread their energy and effort- emotional, intellectual, imaginative, spiritual and physical-among key priority areas. The neglect of any point, may threaten the vitality of the whole organization.

\section{Review Of Literature:-}

Literature review is as follows:

Yasbek (2004) found that work life balance policies are positively associated with the job tenure of the female employees, and moreover the practices of such policies have a great effect on the turnover rate of employees. Worklife balance policies help in reducing the stress and provide a good work place where, there is less chance of accidents in the working and also provide a fair platform for every employee, ultimately enhancing productivity

Chen (2006) reported on young and single that they tend to have less work life conflict issues compared to with those who have childcare and elderly care responsibilities. And also those who work in state sector will face less WLC issues, generally speaking, than those who work in private sector, as competition and performance pressure is relatively lower in the sector than in the private sector. Similarly, the level of position held and income both have positive relation with the level of WLC in different ways as well as those in higher organizational position tend to feel greater pressure of work which effects their family life negatively. And those who are on less income are less able to commercialize their housework and family care responsibility and experience more-life struggles.

Smith and Gardner, (2007) opined that employees who have been working at an organisation for a longer time than newer employees are thought to be more able to adjust their work commitments with their non work commitments. These same people however probably have greater responsibility at work and therefore are probably less likely to take time off due to non work demands, instead making greater use of work-life balance initiatives . These employees are also more aware of the existence of work-life balance initiatives within the firm, and are therefore more likely to use them in comparison to newer employees who may not even know that they exist.

Shanti and Sundar (2012) in their study of work-life balance of women employees in IT industry analyzed that programs implemented by IT firms of Chennai satisfy different categories of employees differently. Data were collected from 350 women employees working in various IT companies. The study measured the satisfaction levels of the respondents across various work-life balancing parameter. 55\% of the employees were highly satisfied with the current work-life initiatives.

The study of Ajith. et al (2013) on work-life balance for role prioritization of IT employees showed that the employees were able to fulfill their professional and personal commitments at the same time, because of better work-life balance policies. The relationship between work-life balance policies and role prioritization was significant. The study was conducted on variables like travelling time, depression, temper, work etc., to know the relation between work-life balance and stress management.

From the above studies, it can be concluded that the length of service has negative and positive relationship with work life balance. Even then more studies revealed that individual with lesser experience, experienced more stress as compared to the individual with more service years.

\section{Purpose Of The Study:-}

Therefore it is intended to study how exactly the variable "service tenure" impact the WLB satisfaction of software professionals.

\section{Research Methodology:- \\ Sampling and Data Collection:-}

The sample of the study was drawn from software employees in the Hi-tech city in Hyderabad. As the software professionals in an organization belong to different designations, the population is divided into strata based on designation, and from these strata the sample is selected through convenience sampling from the select 10 IT organizations with a focus on a fraction of their software professionals. (E.g. Project leaders, software engineers and trainee engineers). The data is collected through a structured questionnaire consisting of 20 items administered to 500 employees on a likert's scale ranging from strongly agree (5) to strongly disagree (1) 
Hypotheses of the study:-

$\mathbf{H}_{\mathbf{a}}$ : There is a significant impact of "service tenure" on work life balance satisfaction of Software professionals.

Table 1:- Showing the descriptive statistics of the respondents' service tenure scores on Work life balance satisfaction of the sample

\begin{tabular}{|l|l|l|l|}
\hline Service tenure & \multicolumn{1}{|c|}{$\mathrm{N}$} & Mean & Std Dev \\
\hline Less than 1 year & 174 & 1.81 & 1.26 \\
\hline $1-3$ years & 229 & 2.17 & 1.39 \\
\hline 3-5 years & 64 & 2.72 & 1.51 \\
\hline More than 5 years & 33 & 2.36 & 1.45 \\
\hline \multicolumn{1}{|c|}{ Total } & $\mathbf{5 0 0}$ & & \\
\hline
\end{tabular}

Source: primary data

According to Table 1: the means of WLB Satisfaction Score of respondents with higher experience is generally higher than the mean of respondents who have less experience. This is suggestive that years of experience could have an impact on the work life balance satisfaction score. The WLB Satisfaction Score for the class interval "More than 5 years" is lower than the mean for the previous class intervals. This could be due to higher proportion of women among the respondents in this class interval.

Pearson Coefficient Of Correlation:-

In order to measure the extent of linear relationship between the average "service tenure" scores and the average employee work life balance satisfaction scores, Karl Pearson coefficient of correlation is computed; and is tested for significance.

Table 2:- Showing Pearson Coefficient of Correlation between WLB Satisfaction Score and Service tenure

\begin{tabular}{|l|l|l|l|}
\hline \multirow{3}{*}{ WLB satisfaction } & & WLB satisfaction & Service tenure \\
\cline { 2 - 4 } & Pearson Correlation & 1 & $.183^{* *}$ \\
\cline { 2 - 4 } & Sig. (2-tailed) & & .000 \\
\hline \multirow{3}{*}{ Service tenure } & Pearson Correlation & 500 & 500 \\
\cline { 2 - 4 } & Sig. (2-tailed) & $.183^{* *}$ & 1 \\
\cline { 2 - 4 } & $\mathrm{N}$ & 500 & 500 \\
\hline
\end{tabular}

** Correlation is significant at .05 levels (2- tailed)

Table 2 reveals that there is a positive linear correlation (Pearson Correlation) between Employee Work Life Balance Satisfaction Score and service tenure in the organization. ( $\mathrm{r}=.183$ ). The two tailed significance value of 0.000 is suggestive that the correlation is statistically significant. This reflects that respondents with long service tenure in the organization have a higher WLB satisfaction score than respondents with short service tenure. In order to find out the difference in the means of WLB satisfaction between service tenure scores, a test of one way ANOVA is conducted and the results are given in Table 3

Table 3:- Showing ANOVA for WLB Satisfaction Score and Service tenure

\begin{tabular}{|l|l|l|l|l|l|}
\hline & Sum of Squares & df & Mean Square & F & Sig. \\
\hline Between Groups & 42.135 & 3 & 14.045 & 7.558 & .000 \\
\hline Within Groups & 921.673 & 496 & 1.858 & & \\
\hline Total & 963.808 & 499 & & & \\
\hline
\end{tabular}

\section{Significant at .05 levels}

The F statistic and the significance level at 0.000 suggest that the difference in means of WLB Satisfaction Score between service tenures is significant at .05level. To establish the extent to which service tenure in the present organization determines WLB satisfaction score a uni-variate regression of WLB satisfaction score on service tenure was done. 


\section{Coefficient of Determination:-}

Table 4 and 5 give the model summary and results respectively of the simple regression of WLB Satisfaction Score on service tenure.

Table 4:- Showing Model Summary: Simple Regression of WLB Satisfaction Score on service tenure

\begin{tabular}{|c|c|c|c|c|c|c|c|c|c|}
\hline \multirow[b]{2}{*}{ Model } & \multirow[t]{2}{*}{$\mathrm{R}$} & \multirow{2}{*}{$\begin{array}{l}\mathrm{R} \\
\text { Square }\end{array}$} & \multirow{2}{*}{$\begin{array}{ll}\text { Adjusted } & \mathrm{R} \\
\text { Square } & \end{array}$} & \multirow{2}{*}{$\begin{array}{l}\text { Std. Error of } \\
\text { the Estimate }\end{array}$} & \multicolumn{5}{|c|}{ Change Statistics } \\
\hline & & & & & $\begin{array}{l}\mathrm{R} \text { Square } \\
\text { Change }\end{array}$ & $\begin{array}{l}\text { F } \\
\text { Change }\end{array}$ & df1 & $\mathrm{df} 2$ & $\begin{array}{l}\text { Sig. F } \\
\text { Change }\end{array}$ \\
\hline 1 & $.183^{\mathrm{a}}$ & .033 & .032 & 1.368 & .033 & 17.230 & 1 & 498 & .000 \\
\hline
\end{tabular}

Significant at .05 levels

Table 5:- Coefficient of Determination Results: Simple Regression of WLB Satisfaction Score on Service Tenure

\begin{tabular}{|l|l|l|l|l|l|l|}
\hline \multicolumn{2}{|l|}{ Model } & Un-Standardized Coefficients & Standardized Coefficients & t & \multirow{2}{*}{ Sig. } \\
\cline { 3 - 8 } \multicolumn{2}{l|}{} & B & Std. Error & Beta & & \\
\hline & (Constant) & 1.561 & .150 & & 10.423 & .000 \\
\cline { 2 - 7 } & Service tenure & .297 & .071 & .183 & 4.151 & .000 \\
\hline
\end{tabular}

The model summary indicates that the F-change is significant. The significance of the constant and the beta coefficients (alpha $<0.01)$ indicate that years of experience in the present company as a predictive ability on WLB Satisfaction Score and that the former can be used to estimate the latter.

The linear expression of the two can be written as:

\section{WLB Satisfaction Score $=1.561+.297 *$ Service Tenure}

Respondents with more service tenure in the organization, have more WLB Satisfaction Score than respondents with less service tenure in the organization.

\section{Discussion of Results:-}

As far as service tenure is concerned, it is interesting to observe that employees with 3-5 years working in the present organization have a high WLB satisfaction ( Mean $=2.72, \mathrm{SD}=1.51$ ) compared to employees who are having short service tenure of less than one year ( Mean =1.81, SD=1.26). The correlation of service tenure with WLB satisfaction score was .183 significant at .000 levels. And also the ANOVA test for difference of means between men and women significant to a level of .000. ( $\mathrm{p}<.05$ level). The regression of WLB satisfaction scores on service tenure reveals that the WLB scores increases by .297 for every two additional years in the organization. This could be due to the learning curve effects of better management of time, and better management of family issues with the available resources. And the entry level employees have a lot of adjustment problems to be taken care of in the beginning of their career. The causality could also be the other way round given that employees with low current WLB satisfaction quit their jobs and move to new organizations.

\section{Limitations:-}

It is always a matter of chance, how much true information is provided by the respondents. their opinion may be biased because of their subjective perceptions. The study is conducted only in 10 IT organizations in Hyderabad. So it may not give the exact picture of the IT industry with respect to WLB satisfaction levels.

\section{Suggstions And Implications For Future Research:-}

Employees with long service tenure in the current organization have higher WLB satisfaction than employees with short service tenure in the organization.WLB satisfaction based on service tenure in the current organization revealed that the employees who have a service tenure of less than one year faced more work/life challenges with a mean score of 1.81 as compared to other employees whose average satisfaction score has increased from 2.17 to 2.36 as the service tenure increased from 1-3 years to 5 years and above respectively. The present study found the surprising results that the entry level employees are more vulnerable to WLB challenges and have low WLB satisfaction. This research work has been carried out by taking software professionals as a sample, whereas future research can be focused by taking different samples like employees belonging to different managerial levels and comparing between the levels. Further research regarding WLB of single in marital status also should be in depth studied, since there were very few studies done in this regard. 


\section{Conclusion:-}

IT sector is one of the fastest growing sectors and is knowledge intensive in nature. Due to this, it can be said that the satisfaction of the employees is a higher predictor of organizational productivity for IT organizations. The study reveals that work-life balance is becoming a challenging issue in IT sector in India. Service tenure is found to have strong positive correlation with WLB due to the nature of the industry. It is essential that HR departments are responsive to the needs and constantly changing requirements of workforce and the effect of environmental issues in order to improve programs and policies related to work hours thereby saving the cost of hiring by improving work life balance satisfaction.

\section{References:-}

1. Alam, M.S., Biswas, K., \& Hassan, K. (2009). A Test of association between working hour and work family conflict: A glimpse on Dhaka's female white collar professionals. International Journal of Business and Management, 4(5), 27-35.

2. Allen, T. D. (2001). Family-supportive work environments: The role of organizational perceptions. Journal of Vocational Behaviour, 58(3), 414-435.

3. Chen.Q.," Research on work/family conflict of knowledge worker and its intervention strategies", unpublished masters dissertations, changing universities, China, 2006.

4. Choudhary, M, 2013. Work Life Balance:-A challenge for Women employees in India. International Journal of innovative research and studies, vol 2 , Issue 4

5. Helen Lingard and Anna Sublet, (2002), The impact of job and organizational demands on Marital or relationship satisfaction and conflict Among Australian civil engineers, Construction Management and Economics, 20, pp 507-521

6. Macky. K., \& Boxall, P.L. (2008). High involvement work processes, work ntensification and employee well being: a study of New Zealand worker experiences. Asia Pacific Journal of Human Resources, 46(1), 38-55.

7. Major, D. A., Fletcher, T. D., Davis, D. D., \& Germano, L. M. (2008). The influence of work-family culture and workplace relationships on work interference with family: A multilevel model. Journal of Organizational Behavior, 29, 881-897.

8. Mayo, M., Pastor, J.C., \& Sanz, A.I. (2008). Enabling managers to achieve work family balance: A demandscontrol model of housework behaviour and family satisfaction. IE Business School Working Paper WP08-20. Retrieved October 5, 2011, from http://ssrn.com/ abstract=1138789

9. Smith, J. \& Gardner, D. (2007). Factors affecting employee use of work-life balance initiatives. New Zealand Journal of Psychology, 36(1), 3-10.

10. Spector; Cary L Cooper; Steven Poelmans; Tammy D Allen; et al "(2004) A Cross - national comparative study of work-family stressors, working hours", Personnel Psychology; Spring; 57, 1; ABI/INFORM Global pg. 119

11. Steiber, N. (2009). Reported levels of time-based and strain-based conflict between work and family roles in Europe: A multilevel approach. Social Indicators Research, 93 , 469-488.

12. White, M., Hill, S., McGrovern, P., Collins, M., \& Smeaton, D. (2003). High-performance management practices, working hours and work-life balance. British Journal of Industrial Relations, 41(2), 175-195.

13. Yadav, R. K., \& Dabhade, N. (2013). Work Life Balance And Job Satisfaction Among The working Women Of Banking And Education Sector -A Comparative Study.International Journal of Advancement in Education and Social Sciences, 1(2), 17-30.

14. Yasbek, P., "The business case for firm-level work-life balance policies: a review of the Literature, Labour Market Policy Group", Department of Labour, 2004. 